\title{
Establishment and evaluation of an indirect ELISA for detection of antibodies to goat Klebsiella pneumonia
}

Ruichang Chen ${ }^{1,2^{*}+}$, Hongqi Shang ${ }^{1,2 \dagger}$, Xiangyun Niu ${ }^{1,2}$, Jin Huang ${ }^{1,2}$, Yongqiang Miao ${ }^{1,2}$, Zhou Sha ${ }^{1,2}$, Liting Qin ${ }^{3}$, He Huang ${ }^{3^{*}}$, Duo Peng ${ }^{4^{*}}$ and Ruiliang Zhu ${ }^{1,2^{*}}$

\begin{abstract}
Background: Klebsiella pneumonia, a Gram-negative bacterium belonging to the genus Enterobacter, causes many human and livestock diseases. Notably, infected goats may develop pneumonia, septicemia, which can lead to occasional death, resulting in great economic losses in goat-farming industry. However, there are little systematic methods for detection of goat Klebsiella pneumoniae in livestock production.

Results: In this study, we developed a Klebsiella pneumoniae goat polyclonal antibody and established an indirect ELISA method to detect the Klebsiella pneumoniae. After screening and optimizing the conditions for detection, we determined the optimal working dilutions of the coated-bacterial antigen, the polyclonal antibody, and the enzyme-labeled secondary antibody that were 1:800 $\left(2.99 \times 10^{7} \mathrm{CFU} / \mathrm{ml}\right), 1: 6400$, and 1:5000, respectively. The optimal condition of coating and blocking were both $4^{\circ} \mathrm{C}$ for $12 \mathrm{~h}$. The optimal dilution buffers of bacterial antigen, the antibodies, and the blocking buffer were $0.05 \mathrm{~mol} / \mathrm{L}$ carbonate buffer, 1\% BSA phosphate buffer, and 1.5\% BSA carbonate buffer, respectively. The cut-off value was determined to be 0.28 , and the analytical sensitivity was 1:800 (dilution of a positive sample). Furthermore, there was no cross-reaction between the coated antigen and goat serum positive for antibodies against other bacteria, indicating that indirect ELISA could detect Klebsiella pneumoniae specifically in most cases. The average coefficients of variation of intra-assay and inter-assay were 4.37 and $5.17 \%$ indicating favorable reproducibility of indirect ELISA. In the detection of clinical veterinary samples, the positive rate of indirect ELISA was $6.74 \%$, higher than that of conventional agglutination assays.
\end{abstract}

Conclusions: Taken together, we successfully established an indirect ELISA method for detecting antibodies against Klebsiella pneumoniae in goats, which can be applied in production.

Keywords: Goat Klebsiella pneumonia, Polyclonal antibodies, Indirect ELISA detection method, Optimal working conditions, Clinical veterinary application

\footnotetext{
*Correspondence: 834522948@qq.com; huanghe1@newhope.cn;

dpeng@hsph.harvard.edu; ruiliangzhu_sdau@163.com

${ }^{+}$Ruichang Chen and Hongqi Shang contributed equally to this work.

'Shandong Provincial Key Laboratory of Animal Biotechnology and Disease

Control and Prevention, Shandong Agricultural University, Taian, China

${ }^{3}$ Shandong Newhope Liuhe Group Co., Ltd., Qingdao, China

${ }^{4}$ Department of Immunology and Infectious Diseases, Harvard T.H. Chan

School of Public Health, Boston, MA 02115, USA

Full list of author information is available at the end of the article
}

(c) The Author(s). 2021 Open Access This article is licensed under a Creative Commons Attribution 4.0 International License, which permits use, sharing, adaptation, distribution and reproduction in any medium or format, as long as you give appropriate credit to the original author(s) and the source, provide a link to the Creative Commons licence, and indicate if changes were made. The images or other third party material in this article are included in the article's Creative Commons licence, unless indicated otherwise in a credit line to the material. If material is not included in the article's Creative Commons licence and your intended use is not permitted by statutory regulation or exceeds the permitted use, you will need to obtain permission directly from the copyright holder. To view a copy of this licence, visit http://creativecommons.org/licenses/by/4.0/ The Creative Commons Public Domain Dedication waiver (http://creativecommons.org/publicdomain/zero/1.0/) applies to the data made available in this article, unless otherwise stated in a credit line to the data. 


\section{Background}

Klebsiella pneumoniae is an opportunistic pathogen parasitizing on the respiratory or intestinal tract of human and animals, and probably causes zoonotic disease such as meningitis, pneumonia, urinary tract inflammation, and even sepsis in the clinical veterinary, contributing to enormous potential threats to both human health and livestock production [1]. In China, along with increasing demand of goat livestock, goat husbandry industry has gradually adopted high-density breeding and fast fattening using concentrated feeding pattern [2]. However, in this process, overuse and even abuse of antibiotics contribute to an increase in the number of outbreaks of Klebsiella pneumoniae [3]. Seriously, Klebsiella pneumoniae-caused diseases and other secondary pathogenic bacteria infections eventually result in the death of goats [4]. Thus, an efficient, sensitive, and robust Klebsiella pneumoniae antibody detection method is highly desired to guide the prevention, intervention and control of the spread of Klebsiella pneumoniae in goat-farming industry [5].

Bacterial detection generally depends on phenotype or genotype [6]. Conventional phenotype-based laboratory techniques for the diagnosis of Klebsiella pneumoniae include pure culture, microscopic determination, biochemical examination are labor-intensive, timeconsuming and easily interferred by other bacteria, even though regarded as the gold standards [7]. By contrast, genotype-based techniques are rapid and highly sensitive. Previous studies have established polymerase chain reaction (PCR)-based assays for human and fur-bearing animal (mink, raccoon dog, fox) Klebsiella pneumoniae. PCR technique variants, such as multiplex PCR and realtime PCR methods, are primary diagnostic tools in hospitals and laboratories [8]. There are also novel methods for the detection of Klebsiella pneumoniae, which are demonstrated to be more accurate and sensitive, like automatic bacteria identification system and mass spectrometry [9]. However, these methods could not be conducted on-site and in low resource-setting areas that lack precise equipment and trained personnel [10]. Furthermore, studies on goat-source Klebsiella pneumoniae are generally focused on isolation, identification, and epidemiological investigation while few studies on developing detection methods. Serological assay is also one of the commonly used detection methods in veterinary medicine [11]. In addition to phenotypic and genotypic identification of goat source Klebsiella pneumoniae, agglutination assay is occasionally used for antibody detection, but it has a main disadvantage of poor sensitivity. Indirect enzyme-linked immunosorbent assay (ELISA), one of the serological methods, is efficient, sensitive, specific, easy to operate, and can be scaled-up to apply to a large number of serum samples [12].
In line with this, we obtained a Klebsiella pneumoniae goat polyclonal antibody and established an indirect ELISA method. Furthermore, a total of 1320 serum samples from clinics in Shandong Province were subjected to assess whether our assay is feasible to deploy in clinical veterinary settings. Therefore, the developed an indirect ELISA detection assay is a rapid diagnostic method that could be applied to clinical veterinary diagnosis and epidemiological investigation of goat-sourced Klebsiella pneumonia.

\section{Results \\ Preparation and identification of the Klebsiella pneumoniae goat polyclonal antibody}

Using the agglutination test, we determined the agglutination value of the Klebsiella pneumoniae goat polyclonal antibody to be $9 \log 2$. To identify the specificity of the Klebsiella pneumoniae goat polyclonal antibody, an indirect immunofluorescence assay was performed and there had been clear fluorescence on the Klebsiella pneumoniae smear by using the prepared polyclonal antibody (Fig. 1a). However, the smears of goat Escherichia coli and Pasteurella showed weak fluorescence (Fig. $1 \mathrm{~b}$ and $\mathrm{c}$ ), while the negative control group showed no fluorescence (Fig. 1d). Therefore, our results demonstrated that the Klebsiella pneumoniae goat polyclonal antibody can be used as the positive control serum for the detection of Klebsiella pneumoniae.

\section{Optimization of ELISA indirect conditions}

To search for the optimal reaction condition, we performed a square matrix titration test (Table 1 ). The reaction conditions corresponding to the highest $\mathrm{P} / \mathrm{N}$ values are generally considered to be the optimal conditions. As shown in Table 1, the optimal coating antigen dilution was determined to be $1: 800$, the corresponding antigen concentration is $2.99 \times 10^{7} \mathrm{CFU} / \mathrm{mL}$, and the optimal working dilution of polyclonal antibody is 1: 6400 . The other reaction conditions were optimized by varying a single parameter at a time. The optimum dilution of HRP-conjugated Affinipure Rabbit Anti-Goat IgG was 1: 5000 (Fig. 2a). The optimal buffer for diluting both the polyclonal antibody and HRP-conjugated IgG was $1 \%$ BSA phosphate buffer (Fig. 2b). The antigen was diluted in $0.05 \mathrm{~mol} / \mathrm{L}$ carbonate buffer at $4{ }^{\circ} \mathrm{C}$ for $12 \mathrm{~h}$ during the coating process (Fig. $2 \mathrm{c}$ and $\mathrm{d}$ ). The best blocking solution was determined to be carbonate buffer containing $1.5 \% \mathrm{BSA}$ and the plates were optimally blocked at $4{ }^{\circ} \mathrm{C}$ for $12 \mathrm{~h}$ (Fig. 2e and f). The polyclonal antibody and the HRP-conjugated Affinipure Rabbit Anti-Goat IgG were incubated for $60 \mathrm{~min}$ and $45 \mathrm{~min}$, respectively (Fig. $2 \mathrm{f}$ and $\mathrm{h}$ ). Furthermore, as the $\mathrm{P} / \mathrm{N}$ value of the negative control is higher than 2.1 when the substrate 


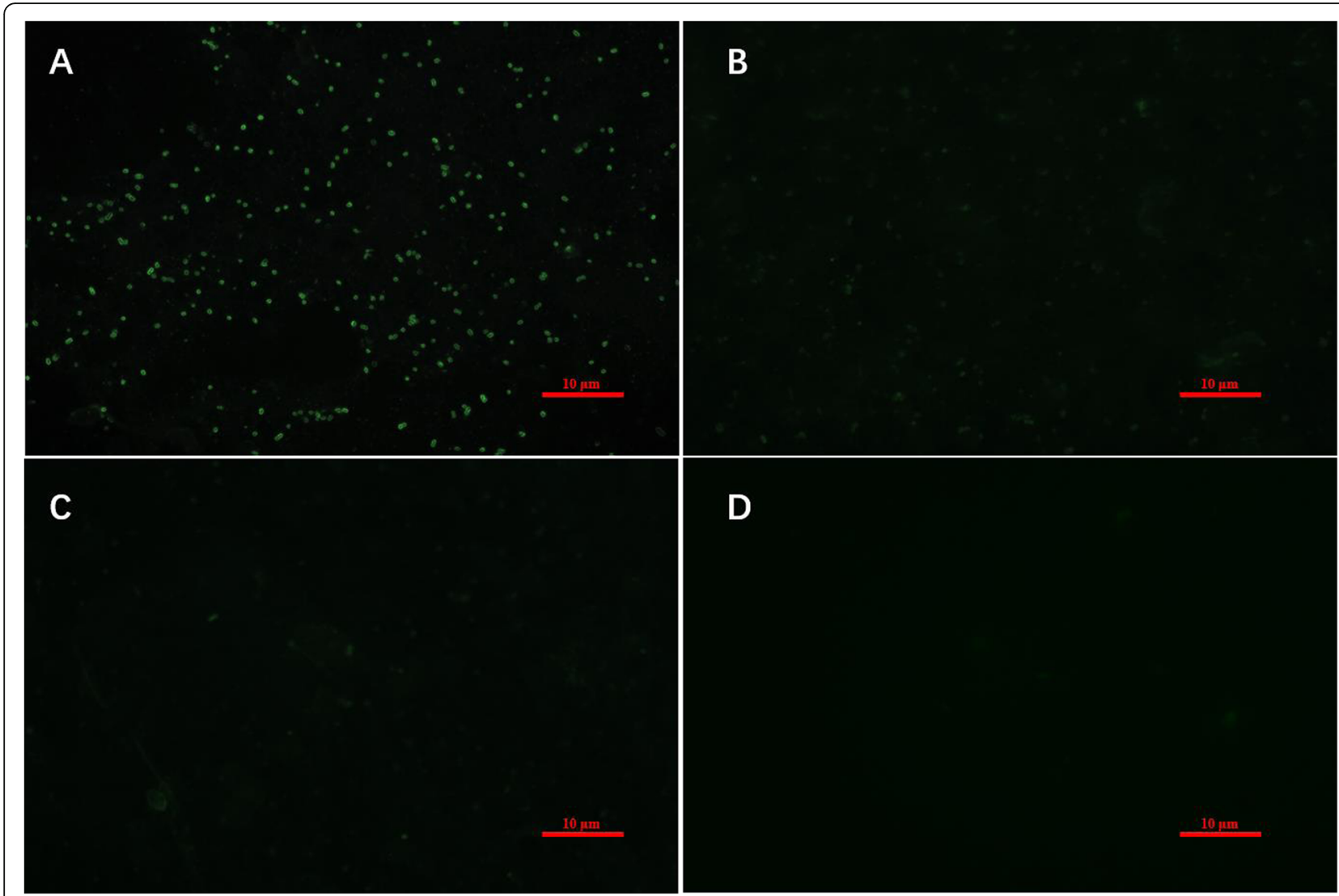

Fig. 1 Indirect immunofluorescence verification of Klebsiella pneumoniae goat polyclonal antibody $(1000 \times)$. Immunofluorescence was performed to detect the specificity of Klebsiella pneumoniae goat polyclonal antibody. A culture containing Klebsiella pneumonia was smeared on the slide and then stained using the Klebsiella pneumoniae goat polyclonal antibody as the primary antibody and FITC-labeled goat anti-rabbit IgG as the secondary antibody (a). Smears of Escherichia coli (b) and Pasteurella (c) were immunofluorescent stained by using the same polyclonal antibody. Smear without bacteria served as the negative control (d)

was incubated for $40 \mathrm{~min}$, the optimal reaction time was thereby determined to be $30 \mathrm{~min}$ (Fig. 2i, Table 2).

\section{Determination of cut-off value of indirect ELISA}

To determine cut-off value of positive and negative samples, forty-eight goat negative serum samples without Klebsiella pneumoniae antibodies were detected by the indirect ELISA method. The results showed that the average value of $\mathrm{OD}_{450}$ values was 0.2167 and the standard deviation was 0.0198. According to the previously reported formula, the cut-off value was determined to be 0.28 (Fig. 3). Therefore, we could determine that the goat serum samples are positive if the $\mathrm{OD}_{450}$ value is

Table $1 \mathrm{P} / \mathrm{N}$ values of antigen- antibody indirect ELISA square matrix titration test

\begin{tabular}{|c|c|c|c|c|c|c|c|c|c|c|c|}
\hline \multirow[b]{2}{*}{$\begin{array}{l}\text { Antigen } \\
\text { dilution }\end{array}$} & \multicolumn{11}{|c|}{ Klebsiella pneumoniae goat polyclonal antibody dilutions } \\
\hline & $\begin{array}{l}1: 1.0 \times \\
10^{2}\end{array}$ & $\begin{array}{l}1: 2.0 \times \\
10^{2}\end{array}$ & $\begin{array}{l}1: 4.0 \times \\
10^{2}\end{array}$ & $\begin{array}{l}1: 8.0 \times \\
10^{2}\end{array}$ & $\begin{array}{l}1: 1.6 \times \\
10^{3}\end{array}$ & $\begin{array}{l}1: 3.2 \times \\
10^{3}\end{array}$ & $\begin{array}{l}1: 6.4 \times \\
10^{3}\end{array}$ & $\begin{array}{l}1: 1 .^{28} \times \\
10^{4}\end{array}$ & $\begin{array}{l}1: 2.56 \times \\
10^{4}\end{array}$ & $\begin{array}{l}1: 5.12 \times \\
10^{4}\end{array}$ & $\begin{array}{l}1: 1.024 \times \\
10^{4}\end{array}$ \\
\hline $1: 1 \times 10^{2}$ & 2.119 & 3.036 & 3.063 & 3.165 & 4.456 & 4.760 & 5.061 & 4.700 & 4.565 & 3.272 & 2.311 \\
\hline $1: 2 \times 10^{2}$ & 2.007 & 1.770 & 2.992 & 3.274 & 4.253 & 4.638 & 5.027 & 4.089 & 3.203 & 2.491 & 1.699 \\
\hline $1: 4 \times 10^{2}$ & 1.744 & 2.384 & 2.852 & 3.399 & 4.430 & 4.955 & 4.624 & 3.763 & 2.899 & 2.412 & 1.951 \\
\hline $1: 8 \times 10^{2}$ & 1.631 & 2.263 & 2.729 & 3.198 & 4.081 & 4.989 & 5.122 & 4.421 & 3.449 & 2.281 & 1.699 \\
\hline $1: 1.6 \times 10^{3}$ & 1.629 & 1.881 & 2.719 & 3.388 & 3.919 & 4.243 & 4.677 & 4.705 & 3.341 & 2.342 & 1.699 \\
\hline $1: 3.2 \times 10^{3}$ & 1.487 & 1.716 & 2.124 & 2.607 & 3.522 & 3.302 & 3.586 & 3.442 & 3.290 & 2.579 & 1.932 \\
\hline $1: 6.4 \times 10^{3}$ & 0.808 & 1.670 & 1.979 & 2.407 & 3.393 & 3.260 & 3.703 & 3.579 & 3.210 & 3.202 & 1.573 \\
\hline
\end{tabular}



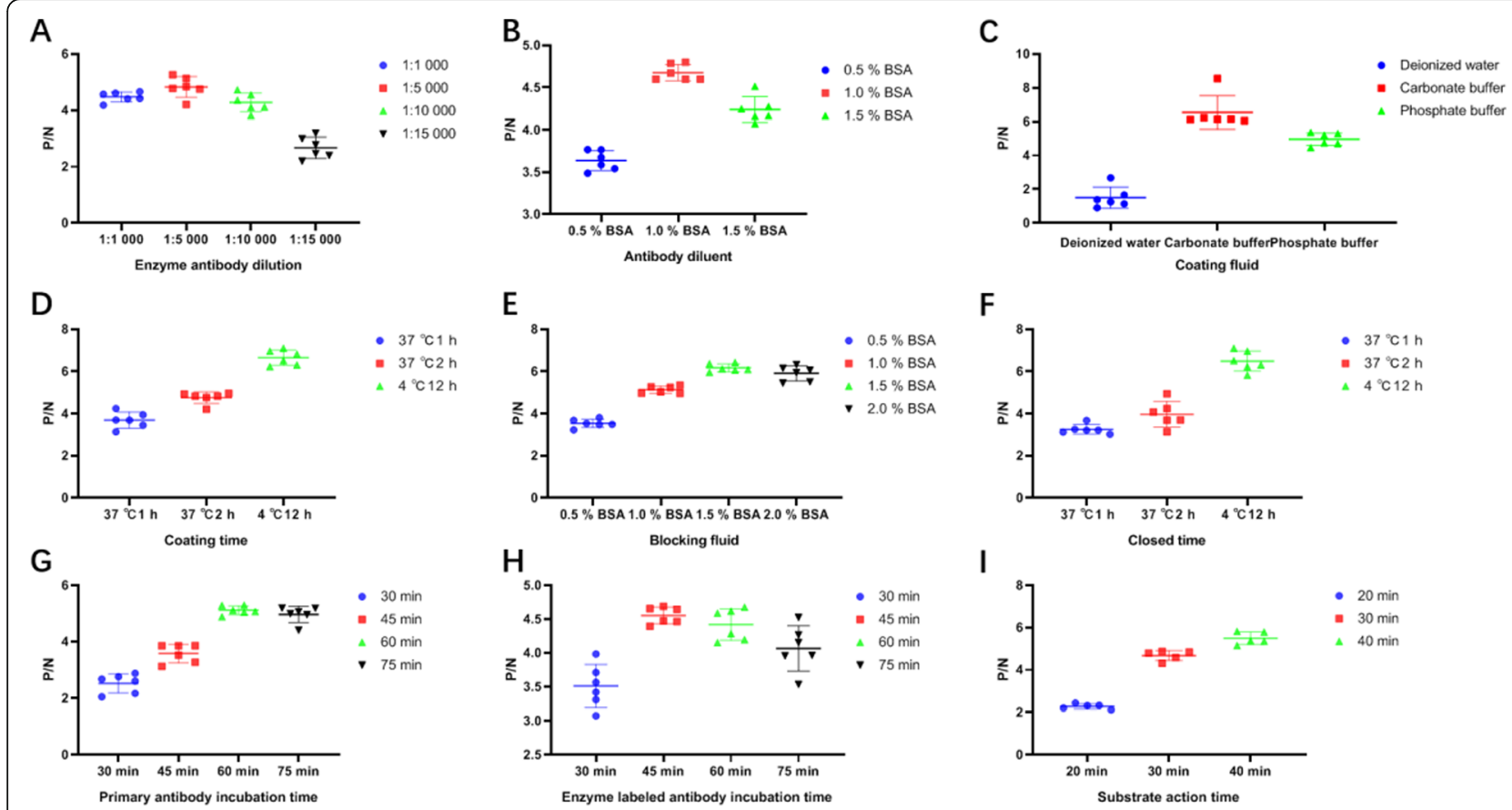

Fig. 2 Optimization of ELISA indirect conditions. The optimal dilution of the HRP-conjugated Affinipure Rabbit Anti-Goat lgG was selected according to the P/N value (a), the antibody buffer (b), coating-buffer (c), coating-time/temperature (d), blocking-buffer (e), blocking-time/ temperature $(\mathbf{f})$, incubation time of the polyclonal antibody $(\mathbf{g})$ and the HRP-conjugated $\operatorname{lgG}(\mathbf{h})$, and chromogenic time (i) were respectively determined in turn

0.28 or above; otherwise, the samples could be determined to be negative.

\section{Sensitivity, specificity, and reproducibility analysis of indirect ELISA}

As shown in Table 3 , the $\mathrm{P} / \mathrm{N}$ value was above 2.1 at a dilution of 1:800 of positive serum, while the corresponding $\mathrm{P} / \mathrm{N}$ value was below 2.1 at a dilution of 1 : 1600. Therefore, the analytical sensitivity of the indirect ELISA method was 1: 800 dilution of serum to be tested.

To investigate the specificity of the indirect ELISA, goat sera that were positive of Escherichia coli, Salmonella, Clostridium perfringens, and Pasteurella were used as the samples and followed by the established procedures. As shown in Fig. 4, the P/N values of positive reactions of Klebsiella pneumoniae positive serum were

Table 2 Selection of substrate reaction time (P/N)

\begin{tabular}{llll}
\hline Samples & $\mathbf{2 0} \mathbf{~} \mathbf{i n}$ & $\mathbf{3 0} \mathbf{~} \mathbf{i n}$ & $\mathbf{4 0} \mathbf{~} \mathbf{~}$ \\
\hline 1 & 2.327 & 4.872 & 5.789 \\
2 & 2.434 & 4.308 & 5.153 \\
3 & 2.115 & 4.836 & 5.817 \\
4 & 2.318 & 4.79 & 5.371 \\
5 & 2.203 & 4.584 & 5.357 \\
Negative & 1.272 & 1.879 & 2.315 \\
\hline
\end{tabular}

above 2.1, while that of negative reactions were below the value. The results indicated that the Klebsiella pneumoniae antigen did not cross-react with other sera, indicating that the established indirect ELISA had a strong specificity.

The reproducibility of the assay was evaluated by determining the average intra-assay and inter-assay CVs. The intra-assay CVs ranged from 1.78 to $7.20 \%$, with a mean of $4.37 \%$ (Table 4 ), while the inter-assay CVs ranged from 4.06 to $6.63 \%$, with a mean of $5.17 \%$ (Table 5). The CVs of all samples was no more than $10 \%$, indicating that the method had good stability and reproducibility.

\section{Clinical veterinary application of indirect ELISA}

A total of 1320 goat sera samples were tested for Klebsiella pneumoniae by the indirect ELISA and agglutination assay simultaneously. Our results showed that the positive samples detected by agglutination assay were also determined to be positive by the indirect ELISA. Moreover, the number of positive samples detected by indirect ELISA is more than that of agglutination assay, and the positive detection rate of indirect ELISA is $6.74 \%$ higher than that of the agglutination assay. These results suggested that compared with agglutination assay, the indirect ELISA test has higher sensitivity and can be applied for clinical veterinary detection of Klebsiella 


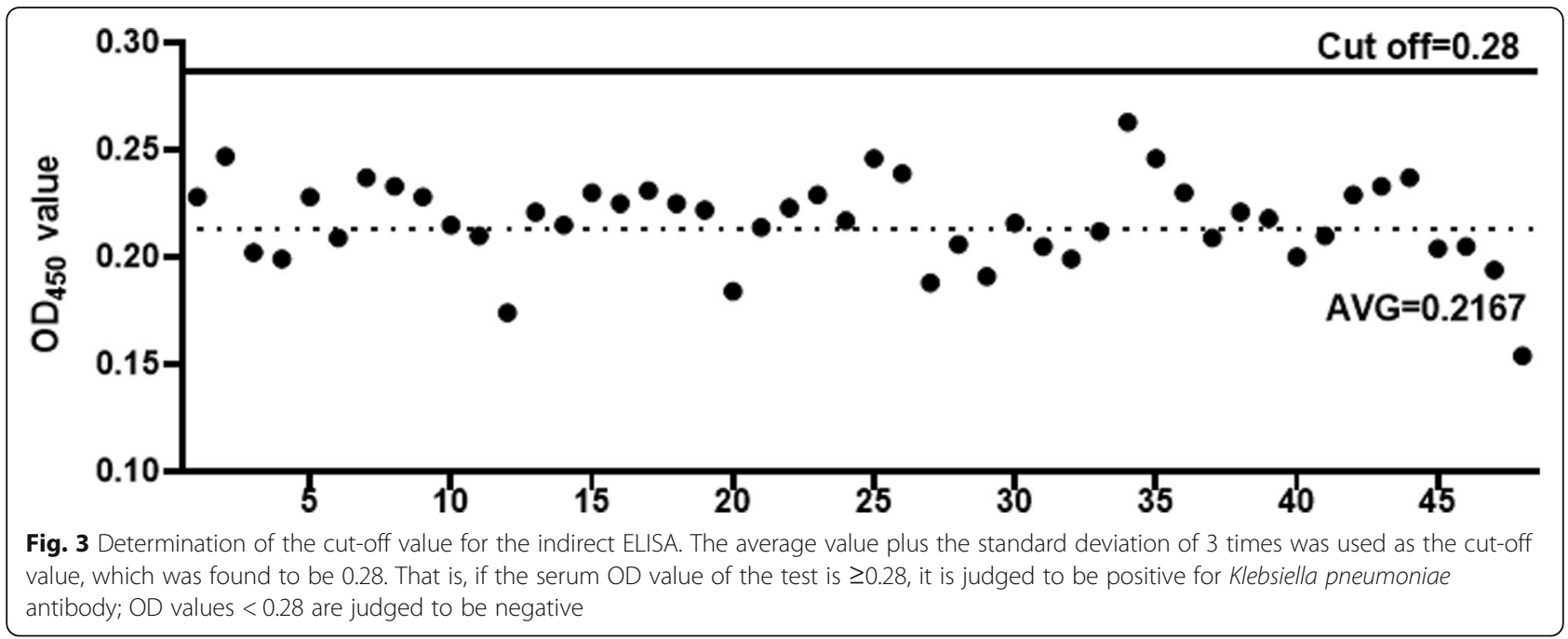

pneumoniae in goat husbandry (Table 6). Furthermore, to avoid false positives of indirect ELISA, the goats determined to be Klebsiella pneumoniae positive by using indirect ELISA but negative according to agglutination assay were tracked to the goat farms according to the Sample IDs and examine their physical conditions, including temperature, mental state, and whole blood cell analysis. The percentage of ELISA positive animals showing clinical symptoms was $80.9 \%$ (positive rate $72 /$ 89).

\section{Discussion}

Klebsiella pneumoniae is one of the most common Gram-negative pathogens posing a huge threat to human and animal health. In the livestock farming industry, Klebsiella pneumoniae could cause goat pneumonia, intracerebral hemorrhage or even death due to unsanitary living conditions. Furthermore, emerging antibiotic resistance in some strains of Klebsiella pneumoniae have added to this challenge. Therefore, the early detection of Klebsiella pneumoniae has become extremely crucial.

Currently, isolation and cultivation and agglutination assay are primary methods for the detection of Klebsiella pneumonia in goats [13]. ELISA is a sensitive technique based on antigen-antibody binding and signalpropagation using enzymatic reactions [14]. Compared with $16 \mathrm{~s}$ rRNA assay, multiple PCR techniques or realtime fluorescence quantitative PCR method established in other animals, ELISA does not require complicated equipments and is not labor-intensive [15]. Previous studies have reported an indirect ELISA for the differentiation of major Enterobacteriaceae from glucose nonfermenters, in the context of urinary tract and bloodstream infection [16]. This anti-gram negative bacteria (GNB) indirect ELISA can be used to differentiate Escherichia coli from other species of Enterobacteriaceae, including Klebsiella pneumoniae, but it cannot detect Klebsiella pneumoniae directly because of the absence of the corresponding antibodies [16]. In this study, we prepared a Klebsiella pneumoniae goat polyclonal antibody and evaluated its specificity by immunofluorescence assay. The results showed strong and specific fluorescent signals response to Klebsiella pneumoniae smears, demonstrating its suitability as a primary antibody for the detection of Klebsiella pneumoniae in an immunoassay. Subsequently, an indirect ELISA based on Klebsiella pneumonia was established by using the bacterial antigen as coated antigen and the Klebsiella pneumoniae goat polyclonal antibody as the primary antibody. The reaction conditions of indirect ELISA were optimized on the basis of $\mathrm{P} / \mathrm{N}$ values [17].

Then, the method was evaluated by sensibility, specificity, reproducibility, and clinical veterinary assay efficacy. Our results show that the sensitivity of the Klebsiella pneumoniae indirect ELISA method was 1: 800, which was significantly higher than conventional agglutination

Table 3 Indirect ELISA sensitivity measurement

\begin{tabular}{llllll}
\hline & \multicolumn{5}{c}{$\mathbf{O D}_{\mathbf{4 5 0}}$ values of different dilutions of the Klebsiella pneumoniae positive and negative serum } \\
\hline Bacterial dilution & $1: 100$ & $1: 200$ & $1: 400$ & $1: 800$ & $1: 1600$ \\
$1: 800$ & $0.892(+)$ & $0.758(+)$ & $0.324(+)$ & $0.293(+)$ & $0.241(-)$ \\
$1: 800$ & $0.162(-)$ & $0.163(-)$ & $0.152(-)$ & $0.126(-)$ & $0.146(-)$ \\
\hline
\end{tabular}

Note: (+) means positive serum, (-) means negative serum 


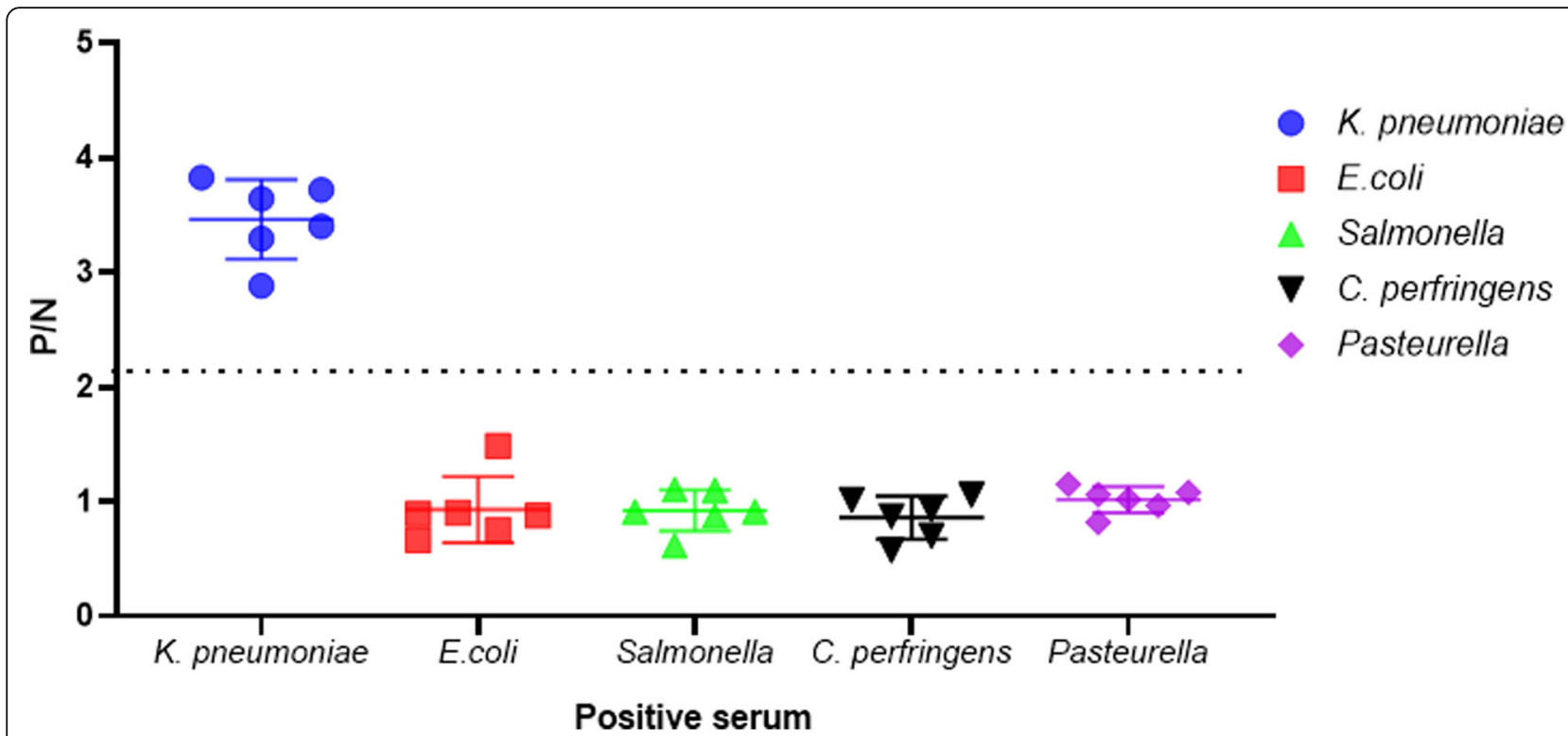

Fig. 4 Specificity analysis of the indirect ELISA. Positive goat serum for common pathogens, including Klebsiella pneumoniae, Escherichia coli, Salmonella, Clostridium perfringens, and Pasteurella were detected by the indirect ELISA and the P/N values were recorded. The P/N values of the other four anti-serums were below 2.1 except that of Klebsiella pneumoniae

assay. The antigenic cross-reactivity test results indicated that the indirect ELISA did not cross-react with antibodies against common bacteria and was capable of detecting anti-sera to Klebsiella pneumoniae. Both the intra-assay and inter assay CVs were lower than $10 \%$, which suggested that the method has good reproducibility [18]. To further evaluate the efficacy of the method, additional tests in clinical veterinary settings are essential. We examined 1320 serum samples from goat farms in Shandong Province using the indirect ELISA and agglutination assay simultaneously. Generally, animals produce relatively low antibody level in the early stages of bacterial infection. Therefore, we could not conclude the absence of Klebsiella pneumoniae even if the agglutination test failed to detect antibodies in serum [19]. Even though there are several positive results present in old infections or other pathogen infections, these results are sufficient to indicate that the ELISA we have established has low false positives. The indirect ELISA exerted a higher positive rate sensitivity of Klebsiella pneumoniae than that of agglutination assay, which suggested that developed indirect ELISA might be a promise tool for early detection of Klebsiella pneumonia. Taken together, these results indicate the sensitivity, specificity and stability of our indirect ELISA method and its potential utility of detecting Klebsiella pneumoniae in both clinical veterinary settings and the goat-farming industry.

Table 4 Intra-assay of indirect ELISA

\begin{tabular}{|c|c|c|c|c|c|c|c|c|c|}
\hline \multirow{2}{*}{$\begin{array}{l}\text { Serum } \\
\text { number }\end{array}$} & \multicolumn{6}{|c|}{ ELISA plate batch $\left(\mathrm{OD}_{450}\right.$ values) } & \multirow{2}{*}{$\begin{array}{l}\text { Average } \\
\text { (X) }\end{array}$} & \multirow{2}{*}{$\begin{array}{l}\text { Standard } \\
\text { deviation } \\
\text { (SD) }\end{array}$} & \multirow{2}{*}{$\begin{array}{l}\text { Coefficient } \\
\text { of } \\
\text { variation } \\
\text { (CV\%) }\end{array}$} \\
\hline & A1 & A2 & A3 & A4 & A5 & A6 & & & \\
\hline P1 & 1.196 & 1.249 & 1.361 & 1.296 & 1.362 & 1.321 & 1.298 & 0.0597 & 4.60 \\
\hline P2 & 1.122 & 1.227 & 1.241 & 1.254 & 1.177 & 1.255 & 1.213 & 0.0483 & 3.98 \\
\hline P3 & 1.205 & 1.202 & 1.281 & 1.216 & 1.259 & 1.164 & 1.221 & 0.0386 & 3.16 \\
\hline P4 & 1.099 & 1.141 & 1.124 & 1.079 & 1.113 & 1.101 & 1.110 & 0.0197 & 1.78 \\
\hline N1 & 0.177 & 0.186 & 0.16 & 0.164 & 0.184 & 0.174 & 0.174 & 0.0096 & 5.49 \\
\hline N2 & 0.189 & 0.19 & 0.175 & 0.154 & 0.183 & 0.191 & 0.180 & 0.0130 & 7.20 \\
\hline N3 & 0.192 & 0.199 & 0.174 & 0.195 & 0.182 & 0.186 & 0.188 & 0.0084 & 4.46 \\
\hline N4 & 0.183 & 0.168 & 0.174 & 0.188 & 0.174 & 0.188 & 0.179 & 0.0076 & 4.26 \\
\hline
\end{tabular}

Note: P1-P4 are positive serum samples for Klebsiella pneumoniae, N1-N4 are negative serum samples, and A1-A6 are samples from the same batch 
Table $\mathbf{5}$ Inter-assay of indirect ELISA

\begin{tabular}{|c|c|c|c|c|c|c|c|c|c|}
\hline \multirow{2}{*}{$\begin{array}{l}\text { Serum } \\
\text { number }\end{array}$} & \multicolumn{6}{|c|}{ ELISA plate batch $\left(\mathrm{OD}_{450}\right.$ values) } & \multirow{2}{*}{$\begin{array}{l}\text { Average } \\
\text { (X) }\end{array}$} & \multirow{2}{*}{$\begin{array}{l}\text { Standard } \\
\text { deviation } \\
\text { (SD) }\end{array}$} & \multirow{2}{*}{$\begin{array}{l}\text { Coefficient } \\
\text { of } \\
\text { variation } \\
\text { (CV\%) }\end{array}$} \\
\hline & A2 & B2 & $\mathrm{C} 2$ & D2 & E2 & F2 & & & \\
\hline P5 & 0.899 & 0.905 & 0.912 & 0.988 & 0.88 & 0.825 & 0.902 & 0.0482 & 5.34 \\
\hline P6 & 0.997 & 0.892 & 0.897 & 0.968 & 0.993 & 0.909 & 0.943 & 0.0446 & 4.73 \\
\hline P7 & 0.89 & 0.824 & 0.889 & 0.871 & 0.958 & 0.931 & 0.894 & 0.0427 & 4.78 \\
\hline P8 & 0.871 & 0.853 & 0.805 & 0.804 & 0.914 & 0.914 & 0.860 & 0.0450 & 5.23 \\
\hline N5 & 0.232 & 0.228 & 0.244 & 0.228 & 0.214 & 0.238 & 0.231 & 0.0094 & 4.06 \\
\hline N6 & 0.126 & 0.118 & 0.135 & 0.119 & 0.134 & 0.113 & 0.124 & 0.0082 & 6.63 \\
\hline N7 & 0.224 & 0.217 & 0.213 & 0.221 & 0.211 & 0.185 & 0.212 & 0.0128 & 6.04 \\
\hline N8 & 0.167 & 0.164 & 0.186 & 0.183 & 0.173 & 0.176 & 0.175 & 0.0079 & 4.52 \\
\hline
\end{tabular}

Note: P1-P4 are positive serum samples for Klebsiella pneumoniae, N1-N4 are negative serum samples, and A2-F2 are samples from 6 different batches

Since goats raised in farms (in China) do not receive vaccines protecting them against Klebsiella pneumoniae, we could diagnose a goat infected with Klebsiella pneumoniae only by detecting whether the serum contained the corresponding antibodies. The major problem is that the current methods are time-consuming and laborintensive, and are less amenable to scaling up. Hence, the key to controlling and preventing Klebsiella pneumoniae infection is identifying infected goats timely, improving the intestinal microflora of goats, and reducing economic losses caused by Klebsiella pneumoniae infection. Although our studies have few shortcomings, including the use of the whole bacteria as coated antigen instead of representative Klebsiella pneumoniae surface antigens, the lack of screening for monoclonal antibodies against Klebsiella pneumoniae, and inevitable false positives of ELISA, which we are currently pursuing. Nevertheless, our indirect ELISA method paved the road for the early detection of Klebsiella pneumoniae infection in goats. In addition, our data showed that the method has the characteristics of simple, sensitive, specific, and it is suitable for large-scale clinical veterinary testing, which could be used as a serological method for Klebsiella pneumoniae antibodies detection in goats.

\section{Conclusion}

Collectively, we successfully established an indirect ELISA method for detecting antibodies against Klebsiella

Table 6 Clinical veterinary investigation of antibodies against Klebsiella pneumoniae using the indirect ELISA and agglutination test

\begin{tabular}{|c|c|c|c|c|c|c|c|c|}
\hline \multirow{2}{*}{$\begin{array}{l}\text { Serum } \\
\text { source }\end{array}$} & \multirow[t]{2}{*}{ Total } & \multicolumn{2}{|l|}{ Indirect ELISA } & \multicolumn{2}{|l|}{ Agglutination test } & \multirow{2}{*}{$\begin{array}{l}\text { Co- } \\
\text { positive }\end{array}$} & \multirow{2}{*}{$\begin{array}{l}\text { Negative } \\
\text { samples }\end{array}$} & \multirow{2}{*}{$\begin{array}{l}\text { Coincidence } \\
\text { rate }\end{array}$} \\
\hline & & Positive samples & Positive rate & Positive number & Positive rate & & & \\
\hline Jinan & 60 & 6 & $10.00 \%$ & 1 & $1.67 \%$ & 1 & 53 & $16.67 \%$ \\
\hline Zaozhuang & 120 & 3 & $2.50 \%$ & 0 & $0.00 \%$ & 0 & 117 & $0.00 \%$ \\
\hline Qingdao & 60 & 9 & $15.00 \%$ & 1 & $1.67 \%$ & 1 & 50 & $11.11 \%$ \\
\hline Linyi & 60 & 1 & $1.67 \%$ & 0 & $0.00 \%$ & 0 & 59 & $0.00 \%$ \\
\hline Zibo & 60 & 4 & $6.67 \%$ & 0 & $0.00 \%$ & 0 & 56 & $0.00 \%$ \\
\hline Liaocheng & 120 & 12 & $10.00 \%$ & 2 & $1.67 \%$ & 2 & 106 & $16.67 \%$ \\
\hline Yantai & 60 & 1 & $1.67 \%$ & 0 & $0.00 \%$ & 0 & 59 & $0.00 \%$ \\
\hline Heze & 60 & 8 & $13.33 \%$ & 3 & $5.00 \%$ & 3 & 49 & $37.50 \%$ \\
\hline Jining & 120 & 3 & $2.50 \%$ & 1 & $0.83 \%$ & 1 & 116 & $33.33 \%$ \\
\hline Sunshine & 60 & 2 & $3.33 \%$ & 0 & $0.00 \%$ & 0 & 58 & $0.00 \%$ \\
\hline Binzhou & 60 & 18 & $30.00 \%$ & 4 & $6.67 \%$ & 4 & 38 & $22.22 \%$ \\
\hline Weifang & 120 & 7 & $5.83 \%$ & 1 & $0.83 \%$ & 1 & 112 & $14.29 \%$ \\
\hline Dongying & 120 & 9 & $7.50 \%$ & 2 & $1.67 \%$ & 2 & 109 & $22.22 \%$ \\
\hline Weihai & 60 & 4 & $6.67 \%$ & 1 & $1.67 \%$ & 1 & 55 & $25.00 \%$ \\
\hline Texas & 120 & 21 & $17.50 \%$ & 4 & $3.33 \%$ & 4 & 95 & $19.05 \%$ \\
\hline Taian & 60 & 2 & $3.33 \%$ & 1 & $1.67 \%$ & 1 & 57 & $50.00 \%$ \\
\hline Total & 1320 & 110 & $8.33 \%$ & 21 & $1.59 \%$ & 21 & 1189 & $19.09 \%$ \\
\hline
\end{tabular}


pneumoniae in goats. We optimized each reaction condition, and finally demonstrated that the method has the advantages of high sensitivity, strong specificity, and excellent stability, which could satisfy requirements of production. The indirect ELISA as a rapid diagnostic kit is promising for the epidemiological investigations and clinical veterinary diagnosis of goat Klebsiella pneumoniae.

\section{Methods}

\section{Experimental strains, animals and serum}

The Klebsiella pneumoniae strain KpY-1 was isolated in 2018 from a goat in Shandong Province and was identified by PCR and sequencing. The titer of Klebsiella pneumoniae was determined to be $10^{6.0} \mathrm{CFU} / \mathrm{mL}$ by Colony-Forming Units (CFU) in Luria-Bertani (LB) agar plates. Positive goat sera for Klebsiella pneumoniae, Escherichia coli, Salmonella Enteritidis, Clostridium perfringens, and Pasteurella multocida type $B$ were collected from infected goats and stored at $-80^{\circ} \mathrm{C}$ in our laboratory. The negative sera were standard goat serum products we purchased randomly (C0265, SL038, and G9023). A total of 1320 serum samples were provided by the Animal Disease Prevention and Control Center of Shandong Province. All of the samples were randomly collected from different farms of 16 cities in Shandong Province.

Four one-year-old Laiwu black goats were provided by Shandong Laiwu Black Goat Seed Farm. After the experiments were completed, the goats were healthy and released.

\section{Preparation of the Klebsiella pneumoniae goat polyclonal antibody}

The four Laiwu black goats were immunized with the prepared Klebsiella pneumoniae white oil adjuvant antigen $\left(4.0 \times 10^{9} \mathrm{CFU} /\right.$ goat $)$ by jugular intramuscular injection for five times with immunization interval of 7 days. The serum was collected after 1 week from the last immunization and prepared for further qualification.

\section{Agglutination assay}

The collected serum was continuously diluted with normal saline and added equivalent the inactivated Klebsiella pneumoniae as antigen. The mixture was adequately reacted for $5-10 \mathrm{~min}$. Then, the highest dilution in which agglutination occurs is the serum titer [20]. The Klebsiella pneumoniae goat polyclonal antibody was feasible when the serum agglutinated and the titers were higher than $8 \log 2$.

\section{Indirect immunofluorescence}

Inactivated Klebsiella pneumoniae culture $\left(2.3 \times 10^{10}\right.$ $\mathrm{CFU} / \mathrm{mL}, 20 \mu \mathrm{L}$ ) was added to a slide and fixed with $10 \%$ formaldehyde for $15 \mathrm{~min}$ at room temperature [21]. After rinsing the slide with PBS three times, nonfat dry milk $(5 \%, 20 \mu \mathrm{L})$ was loaded and incubated at $37^{\circ} \mathrm{C}$ for $30 \mathrm{~min}$. Following complete rinse with PBS for three times, the Klebsiella pneumoniae goat polyclonal antibody (1: 200 diluted, $20 \mu \mathrm{L}$ ) that was mentioned above was loaded and incubated at $37^{\circ} \mathrm{C}$ for $30 \mathrm{~min}$. After the extra primary antibody was rinsed off, FITC-labeled goat anti-rabbit IgG (1: 400 diluted, $20 \mu \mathrm{L}$, Beyotime Biotechnology, China) was loaded and incubated at $37^{\circ} \mathrm{C}$ for 30 min [22]. Finally, the slide was washed with PBS (3 times, $1 \mathrm{~min} /$ time) and the positive fluorescence was observed under a fluorescence microscope (Olympus BX51, China). The culture solution without Klebsiella pneumoniae served as control.

\section{Establishment of the indirect ELISA}

A square titration in 96-well ELISA microplates (BIOFIL, medium binding) was implemented to optimize the conditions for detection according to a classical indirect ELISA protocol [23]. Firstly, the inactivated Klebsiella pneumoniae culture $\left(2.3 \times 10^{10} \mathrm{CFU} / \mathrm{mL}\right)$ was serially diluted from 1:100 to 1:6400. The bacteria solution $(100 \mu \mathrm{L} /$ well) were coated with different buffer (deionized water, phosphate buffer, or carbonate buffer) at $37^{\circ} \mathrm{C}$ for $1 \mathrm{~h}$ or $4{ }^{\circ} \mathrm{C}$ for $12 \mathrm{~h}$. The wells were blocked with different buffers $(0.5 \%$ BSA, $1 \%$ BSA, $1.5 \%$ BSA, or $2 \% \mathrm{BSA}, 250 \mu \mathrm{L} /$ well) at $37^{\circ} \mathrm{C}$ for $1 \mathrm{~h}$ and or $4{ }^{\circ} \mathrm{C}$ for 12 $\mathrm{h}$. The Klebsiella pneumoniae goat polyclonal antibody was serially two-fold diluted from $1: 100$ to $1: 102400$ by using different buffers (0.5\% BSA, $1.0 \%$ BSA, or $1.5 \%$ BSA). The positive and negative sera were diluted to 1 : 100 and served as controls $(100 \mu \mathrm{L} /$ well $)$. Then, the plates were incubated at $37^{\circ} \mathrm{C}$ for various time scale (30 min, $45 \mathrm{~min}, 60 \mathrm{~min}$, or $75 \mathrm{~min}$ ). HRP-conjugated Affinipure Rabbit Anti-Goat IgG $(100 \mu \mathrm{L} /$ well, Proteintech, USA) was optimized with different dilutions (1:1000, 1: $5000,1: 10000$ or $1: 15000)$ by $1 \%$ BSA and different incubation times (30 min, $45 \mathrm{~min}, 60 \mathrm{~min}$ or $75 \mathrm{~min}$ ) at $37^{\circ} \mathrm{C}$. Finally, the plates were reacted with $50 \mu \mathrm{L}$ substrate for various time scales $(20 \mathrm{~min}, 30 \mathrm{~min}, 40 \mathrm{~min}$ ) and were measured with a microplate spectrophotometer (XMark, Bio-Rad) at wavelengths of $450 \mathrm{~nm}$ (OD450). The variant was single during the execution of the entire ELISA protocol and all of the samples were tested in technical triplicates. The positive value $(\mathrm{P})$ was approximately 1.0 , the negative value $(\mathrm{N})$ was below 0.4 , and thereby the maximum ratio between $\mathrm{P}$ and $\mathrm{N}(\mathrm{P} / \mathrm{N})$ was no less than 2.1 , which were considered to be the optimal reaction conditions [24].

\section{Determination of the cut-off value}

The $\mathrm{OD}_{450}$ values of 48 goat negative serum samples were determined by the ELISA method, and the 
experiment was repeated 3 times. The mean and standard deviation of the $\mathrm{OD}_{450}$ values were calculated. The $\mathrm{OD}_{450}$ average value plus the standard deviation of 3 times were used as the cut-off value to determine whether a serum sample was positive or negative by the ELISA.

\section{Sensitivity analysis}

Sensitivity analysis, also known as the lower detection limit, was estimated by end-point titration and was defined as the maximum dilution of the sample detected just above the cut-off value. Therefore, Klebsiella pneumoniae positive sera was serially diluted from 1: 100 to 1: 1600 and was conducted by the indirect ELISA procedures. Each dilution was tested in triplicate and the Klebsiella pneumoniae negative serum samples served as controls.

\section{Specificity analysis}

The ELISA method described above was used to simultaneously detect the OD values of goat-derived sera positive for Klebsiella pneumoniae, Escherichia coli, Salmonella, Clostridium perfringens, and Pasteurella, verifying whether the Klebsiella pneumoniae goat polyclonal antibody cross-reacts with serum positive for other pathogens. The goat-derived sera without antibodies against the above mentioned pathogens served as the negative control.

\section{Reproducibility analysis}

To evaluate the reproducibility of ELISA, intra- and inter-assays variation analyses were conducted by the indirect ELISA. Intra-assay was performed using six different ELISA plates of the same batch, inter-assay was performed using ELISA plates to detect samples from different batches. The coefficients of variation (CVs) were calculated by dividing the standard deviation of the OD value of each tested sample by its mean and multiplying the result by 100 to evaluate the reproducibility of the ELISA.

\section{Field sample application}

The established indirect ELISA assay was applied to determine Klebsiella pneumoniae infection from 1320 clinical veterinary serum samples that were collected from different goat farms in Shandong province from 2018 to 2019.

\section{Abbreviations}

K. pneumoniae: Klebsiella pneumoniae; ELISA: Enzyme linked immunosorbent assay; OD: Optical density; HRP: Horseradish peroxidase; IFA: Indirect immunofluorescence assay; CV: The coefficients of variation

\section{Acknowledgements}

We thank the staff of College of Veterinary Medicine, Shandong Agricultura University, in Tai'an, Shandong Province, China and support of department of
Immunology and Infectious Diseases, Harvard T.H. Chan School of Public Health, in Boston, USA. We would like to thank TopEdit (www.topeditsci. com) for English language editing of this manuscript.

\section{Authors' contributions}

Conceptualization, R. C.; Data curation, R. C.; Formal analysis, R. C. and H. S. Funding acquisition, R. Z.; Investigation, R. C., X. N. and J.H.; Methodology, Z S., Y. M. and H. W.: Project administration, R. Z: Resources, R. Z: Software, Z S., Y. M. and H. S.; Supervision, R. Z., L. H. and D. P.; Validation, R. Z.; Visualization, H. S.; Writing - original draft, R. C. and H. S.; Writing - review \& editing, R. Z. and D. P. All authors have read and agreed to the published version of the manuscript.

\section{Funding}

This project was funded by the National Key Research and Development Program of China (2016YFD0500905), the Modern Agricultural Industry Technology System Foundation of Shandong Province (SDAIT-10-06). These funding agencies are primarily responsible for the collection and interpretation of data during research.

\section{Availability of data and materials}

All data generated or analyzed during this study are included in this published article and supplementary information files.

\section{Declarations}

Ethics approval and consent to participate

The animal study was reviewed and approved by Animal Q8 Protection and Utilization Committee of Shandong Agricultural University (Permit number: 20010510).

Consent for publication

Not applicable.

\section{Competing interests}

The authors declare that there are no conflicts of interest.

\section{Author details}

${ }^{1}$ Shandong Provincial Key Laboratory of Animal Biotechnology and Disease Control and Prevention, Shandong Agricultural University, Taian, China. ${ }^{2}$ Shandong Provincial Engineering Technology Research Center of Anima Disease Control and Prevention, Shandong Agricultural University, Taian, China. ${ }^{3}$ Shandong Newhope Liuhe Group Co., Ltd., Qingdao, China. ${ }^{4}$ Department of Immunology and Infectious Diseases, Harvard T.H. Chan School of Public Health, Boston, MA 02115, USA.

Received: 6 August 2020 Accepted: 25 February 2021

Published online: 05 March 2021

\section{References}

1. Kamal G, Rahul R, Mandira V-B, Ashok S. Chronic pneumonia due to Klebsiella oxytoca mimicking pulmonary tuberculosis. Pneumonol Alergol Pol. 2015:83(5):383-6.

2. Zhang Z, Su X. Development status and countermeasures of large-scale goat breeding. Hubei Anim Husbandry Vet. 2018;39:44-5

3. Jia $\mathrm{H}$, Chen $\mathrm{H}$, Ruan $\mathrm{Z}$. Unravelling the genome sequence of a pandrugresistant Klebsiella pneumoniae isolate with sequence type 11 and capsular serotype KL64 from China. J Glob Antimicrob Resist. 2019:19:40-2.

4. Arezoo T, Nooroldin T, Hossein K, Imane A. Tannic acid degradation by Klebsiella strains isolated from goat feces. Iranian J Microbiol. 2016;8:14.

5. Surgers L, Boyd A, Girard P-M, Arlet G, Decré D. Biofilm formation by ESBLproducing strains of Escherichia coli and Klebsiella pneumoniae. Int J Med Microbiol. 2018;309:13

6. Tominaga T. Rapid detection of Klebsiella pneumoniae, Klebsiella oxytoca, Raoultella ornithinolytica and other related bacteria in food by lateral-flow test strip immunoassays. J Microbiol Methods. 2018;147:43.

7. Wang Y, Yan W, Wang Y, Xu J, Ye C. Rapid, sensitive and reliable detection of Klebsiella pneumoniae by label-free multiple cross displacement amplification coupled with nanoparticles-based biosensor. J Microbio Methods. 2018;149:80-8 
8. Charrouf FO, Hamze M, Mallat H, Achkar M, Dabboussi F. Characterization of resistance genes in 68 ESBL-producing Klebsiella pneumonia in Lebanon. Med Mal Infect. 2014;44(11-12):535-8.

9. Liu W, Shang F, Chen Y, Lan J, Wang L, Chen J, et al. Biochemical and structural analysis of the Klebsiella pneumoniae cytidine deaminase CDA. Biochem Biophys Res Commun. 2019;519:2.

10. Mathevon $Y$, Foucras $G$, Falguières R, Corbiere F. Estimation of the sensitivity and specificity of two serum ELISAs and one fecal GPCR for diagnosis of paratuberculosis in sub-clinically infected young-adult French sheep using latent class Bayesian modeling. BMC Vet Res. 2017;13:230.

11. Martora F, Pinto F, Folliero V, Cammarota M, Dell'Annunziata F, Squillaci G et al. Isolation, characterization and analysis of pro-inflammatory potential of Klebsiella pneumoniae outer membrane vesicles. Microb Pathog. 2019;136: 103719.

12. Shuralev E, Quinn P, Doyle M, Duignan A, Kwok HF, Bezos J, et al. Application of the Enfer chemiluminescent multiplex ELISA system for the detection of Mycobacterium bovis infection in goats. Vet Microbiol. 2011; 154:292.

13. Jankásková J, Horváth ON, Varga R, Arenberger P, Schmidt E, Ruzicka T, et al. Increased sensitivity and high specificity of indirect immunofluorescence in detecting IgG subclasses for diagnosis of bullous pemphigoid. Clin Exp Dermatol. 2018:43:248.

14. Zhou S, Zhang S, Wang M, Cheng A, Zhu D, Chen S, et al. Development and evaluation of an indirect ELISA based on recombinant nonstructural protein $3 \mathrm{~A}$ to detect antibodies to duck hepatitis a virus type 1. J Virol Methods. 2019:268:56.

15. Lu M, Liu Q, Wang X, Zhang J, Zhang X, Shi D, et al. Development of an indirect ELISA for detecting porcine deltacoronavirus IgA antibodies. Arch Virol. 2020;165:56.

16. Jackson N, Wu TZ, Adams-Sapper S, Satoorian T, Geisberg M, Murthy N, et al. A multiplexed, indirect enzyme-linked immunoassay for the detection and differentiation of $E$. coli from other Enterobacteriaceae and $P$. aeruginosa from other glucose non-fermenters. J Microbiol Methods. 2019; 158:52.

17. Zhao N, Lange E, Kubald S, Grund C, Beer M, Harder TC. Distinction of subtype-specific antibodies against European porcine influenza viruses by indirect ELISA based on recombinant hemagglutinin protein fragment-1. BioMed Central. 2013;10:246.

18. Näslund K, Blomqvist G, Vernersson C, Zientara S, Bréard E, Valarcher JF. Development and evaluation of an indirect enzyme-linked immunosorbent assay for serological detection of Schmallenberg virus antibodies in ruminants using whole virus antigen. Acta Vet Scand. 2014;56:71.

19. Yanan L, Hui Z. A high sensitivity fluorescence quantitative microfluidic chip for early detection of bacterial infection. J Shanxi Med Univ. 2018;49:1082-8.

20. Yang, Wei, Yang, Li, Zhang, Zhu, et al. Co-adjuvant effects of plant polysaccharide and propolis on chickens inoculated with Bordetella avium inactivated vaccine. Avian Pathol 2015;44:248.

21. Hong M, Ma B, Lin Z, Zhou X, Geng X, Shen L, et al. Hep-2 cell based indirect immunofluorescence assay for antinuclear antibodies as a potential diagnosis of drug-induced autoimmunity in nonclinical toxicity testing. Regul Toxicol Pharmacol. 2015;71(2):141-7.

22. Nagata N, Shimbo T, Akiyama J, Niikura R, Watanabe K, Oka S, et al. Diagnostic accuracy of indirect immunofluorescence assay for intestinal invasive amebiasis and impact of HIV infection in a non-endemic country. Diagn Microbiol Infect Dis. 2012;74(4):374.

23. Fan JH, Zuo YZ, Yang Z, Pei LH. The development of an indirect ELISA for the detection of antibodies to goose parvovirus in blood serum. Lett Appl Microbiol. 2013;57(1):26-32

24. Kwenti TE, Njunda LA, Tsamul B, Nsagha SD, Assob NJ-C, Tufon KA, et al. Comparative evaluation of a rapid diagnostic test, an antibody ELISA, and a pLDH ELISA in detecting asymptomatic malaria parasitaemia in blood donors in Buea, Cameroon. Infect Dis Poverty 2017;6(1):103.

\section{Publisher's Note}

Springer Nature remains neutral with regard to jurisdictional claims in published maps and institutional affiliations.

\section{Ready to submit your research? Choose BMC and benefit from:}

- fast, convenient online submission

- thorough peer review by experienced researchers in your field

- rapid publication on acceptance

- support for research data, including large and complex data types

- gold Open Access which fosters wider collaboration and increased citations

- maximum visibility for your research: over $100 \mathrm{M}$ website views per year

At BMC, research is always in progress.

Learn more biomedcentral.com/submissions 